\title{
Research on the Collaborative Path of Transforming the Advantages of the Party's Leadership System into the Effectiveness of the Rule of Law in Public Health
}

\author{
Ying Ren \\ Green Development Law Research Center, Guangdong University of Foreign Studies, Guangzhou, China \\ Email: 2052614426@qq.com
}

How to cite this paper: Ren, Y. (2020). Research on the Collaborative Path of Transforming the Advantages of the Party's Leadership System into the Effectiveness of the Rule of Law in Public Health. Open Journal of Leadership, 9, 223-234.

https://doi.org/10.4236/ojl.2020.94014

Received: December 1, 2020

Accepted: December 21, 2020

Published: December 24, 2020

Copyright $\odot 2020$ by author(s) and Scientific Research Publishing Inc. This work is licensed under the Creative Commons Attribution International License (CC BY 4.0).

http://creativecommons.org/licenses/by/4.0/

\begin{abstract}
Adhering to the party's leadership over the rule of law in public health is the fundamental requirement for the transformation of institutional advantages into the effectiveness of public health legal construction. The basic rule of the party leading the construction of the rule of law in public health is mainly reflected in the three aspects of the construction of the rule of law in public health, Party building, state and social affairs. Through the implementation of the party's leadership of the legal construction of public health by the state organs of political power, we can ensure that the principle of the party leading the rule of law in public health runs through the whole process of the construction of the rule of law in public health. The advantages of the party's leadership system are transformed into the collaborative path of public health legal efficiency. We should comprehensively promote the construction of the rule of law in national public health by focusing on the coordinated promotion of the implementation of the rule of law in public health and the legal guarantee system under the leadership of the party, the coordination and cooperation between public health management institutions and other departments, and the effective coordination between the party's leadership and public health law enforcement.
\end{abstract}

\section{Keywords}

The Leadership of the Party, The Rule of Law in Public Health, Collaborative Path

\section{Introduction}

The purpose of this paper is to better promote the advantages of the party's lea- 
dership system and promote the construction of the rule of law in public health. The research structure of this paper is mainly divided into four parts. The first part is the basic law of the party's leadership in the construction of the rule of law in public health. It demonstrates the positive role of the centralized and unified leadership of the party for the construction of the rule of law in public health from three aspects: the construction of the party, the construction of the party, and the state and social affairs. The second part is the mechanism of the party's leading the construction of the rule of law in public health, which discusses the implementation of the party's leadership over the rule of law in public health through the people's Congress, the government, the judicial organs and the supervision organs. The third part is the basic principles of public health legal construction under the leadership of the party, which discusses the basic principles and important principles of the party's leadership of public health legal construction. The fourth part is the collaborative path of public health legal construction under the leadership of the party. Under the leadership of the party, it is of great significance to promote the implementation of the rule of law in public health and the legal guarantee system, as well as the coordination between public health management institutions and other departments.

Adhering to the party's leadership constitutes the fundamental meaning in the process of comprehensively promoting the rule of law. The basic law of the party's leadership in the construction of the rule of law in public health is mainly reflected in three aspects. Firstly, it acts on the construction of the rule of law in public health, which is the core content of the party's leading role in the rule of law in public health. Secondly, it plays an important role in the party's construction, which is the key link of the party's leading role in the rule of law in public health. The third is to act on national and social affairs to ensure that the principle of public health rule of law runs through the whole process of public health legal construction (Edgar Jr. et al., 2003).

As for the construction of public health legal system, guided by Xi Jinping's thought of public health rule of law in the new era, the core content of the party's leading role in public health's rule of law is embodied in providing a fundamental guarantee for the construction of public health and the rule of law. In fact, the party's leadership is the due meaning of the legal construction of public health. Strengthening the leading core position of the party in overall planning and coordinating all parties has become the fundamental guarantee for the legal construction of public health. The role of the party's leadership of the rule of law in public health is to ensure decision-making according to law and promote scientific and democratic decision-making. In the area of public health, the party acts under the rule of law and promotes the construction of public health with a strong sense of public health.

In the aspect of Party building, according to the basic principles of materialist dialectics, the party's leadership plays an important role in guiding the construction of the rule of law in public health. At the same time, the development of the 
rule of law in public health also reacts on the construction of the party itself, forming a perfect governance structure. The process of Party building is inseparable from the development of the rule of law in public health. This has laid an important foundation for the full realization of the rule of law in public health under the leadership of the party, and provided an important guarantee for the implementation of the party's leadership. The change of the party's leadership from policy to law has promoted the progress of the rule of law in public health.

In the aspect of national and social development, the party's leadership plays an important role in promoting national development, organizing and managing society through the organs of state power. In the construction of the rule of law in public health, the realization of the party's leadership over the state and society is realized in the specific practice field through the state power organs and specific organizational and institutional forms. The implementation of the value goal of public health maintenance is guaranteed to the greatest extent from the beginning to the end, and the party's leadership over the rule of law in public health is adhered to, so as to realize the public's leadership which guides the whole process of health legal construction. The full play of the party's leading role in the rule of law in public health is the fundamental guarantee for the realization of the rule of law in public health. We should adhere to the party's leadership over the construction of the rule of law in public health, form a collaborative pattern among the state, the political party, the government and the society through legal channels and legal ways, stimulate the cohesive and United Chinese forces, effectively deal with social contradictions in the new era, and implement the party's line, principles and policies in all aspects of the construction of the rule of law in public health.

\section{The Basic Rule and Action Mechanism of the Party's Leadership in the Construction of the Rule of Law in Public Health}

The mechanism of the party's leading the construction of the rule of law in public health is embodied in the implementation of the party's leadership over the construction of the rule of law in public health through the organs of state power. From the three levels of politics, organization and ideology, we should adhere to the leadership of the party. On the one hand, we should ensure the leading core role of the Party committee. On the other hand, we should give full play to the vital role of the organs of state power. The Fourth Plenary Session of the 18th Central Committee of the Communist Party of China points out that the leadership of the party is realized through the organs of state power.

\subsection{The Implementation of the Party's Leadership of Public Health Law through the People's Congress Is Mainly Manifested in the Party's Leadership of Public Health Legislation}

Adhering to the system of the people's Congress is the fundamental foundation 
of the party's leadership in the construction of the rule of law in public health. From a more fundamental level, the party represents the fundamental interests of the overwhelming majority of the people. In the process of governance, the party provides strong support for the National People's Congress and improves the actual efficiency of public health legislation from the perspective of the exercise of public health legislative power. The leadership mechanism of the rule of law in public health is closely related to the organizational form of a country's political power. The party's leadership through the people's Congress is of great significance in the construction of the rule of law in public health. On the one hand, the Party committee puts forward suggestions according to legal procedures to promote the implementation of the party's will in public health legislation. On the other hand, in the process of legal construction of public health, the party's leadership for the construction of the rule of law in public health is also reflected in the election and appointment of leaders of public health management organs. Party organizations have the right to recommend excellent talents who have been inspected by the organization to the people's Congress, and are good at selecting excellent talents through legal procedures to promote the perfection and perfection of the rule of law in public health. It is of great significance for public health security to ensure the implementation of the party's line, guidelines and policies through the mechanism of the party's leadership in the construction of public health legal norms system. Strengthen and improve the public health legislation under the leadership of the party, lead the public health legislation for the people, form a perfect public health management organization and system guarantee, and implement the party's decision-making and deployment. The guiding mechanism of the construction of public health legal norm system under the leadership of the party is based on the Constitution and law. On the basis of the Constitution and law, adhering to the party's leadership over the work of the people's Congress is to ensure the correct direction of public health legislation and promote the construction of the rule of law in public health to effectively protect public health. It is beneficial to implement the core objectives of public health security in all aspects of the construction of public health laws and regulations system, and realize the institutionalization and standardization of public health management.

\subsection{Through the Implementation of the Government, the Party's Leadership over the Rule of Law in Public Health Focuses on the Party's Guarantee of Public Health Law Enforcement}

People's governments at all levels are an important support for the party to lead the rule of law in public health. The party's guiding responsibility for the political power refers to the leadership at the general principle level, rather than direct decision-making management. It is mainly manifested in political direction, ideological guidance and organizational leadership. On this basis, it is combined with raising the party's proposition into the will of the state through legal procedures, so as to promote the implementation of the party's ideas and promote 
the party's principles and policies in public health. The development of the rule of law itself and the implementation of specific economic and social affairs, in accordance with the law to promote the great process of governance, governance and administration. In the process of legal construction of public health, we should consolidate the legal basis of legalization of the party's ruling position through democratic procedures, and ensure that the central and local people's governments at all levels adhere to Democratic Centralism by formulating major policies and putting forward suggestions. The development path of the rule of law in public health and the mechanism of asking for instructions and reporting should be used to ensure the organic coordination between the core role of the party's leadership and the legal performance of government organs. In the long-term development practice, it has formed a set of system norms and working mechanism to adhere to the party's leadership, and successfully established the greatest advantage of the socialist system. Specific to the party's leadership in the construction of public health rule of law, the mechanism of the party's leadership of the rule of law in public health is based on the rule of law construction and development of public health, and is adapted to the construction of the legal system of public health, which is mainly manifested in the construction of legal norms system, implementation system of public health rule of law, supervision system of public health rule of law, and legal guarantee system of public health From the fundamental direction, development process and implementation effect, it provides three-dimensional, all-round and feasible mechanism support for the party's leadership of public health rule of law.

\subsection{The Implementation of the Party's Leadership over the Rule of Law in Public Health through Judicial Organs Is Mainly Manifested in the Party's Support for Public Health Justice}

The judicial organ is an important guarantee for the party to lead the rule of law in public health. It is the key to realize the independent exercise of judicial power and procuratorial power according to law and improve the party's leadership over judicial organs. The party's leadership is the fundamental guarantee for the construction of China under the rule of law in public health. It is also the dream pursued by the Chinese nation for hundreds of years. It is a strong guarantee for the fundamental interests of the overwhelming majority of the people. The establishment of the legal way for the party to exercise leadership through the organs of state power is of great significance to the construction of legal guarantee for public health. However, the implementation of the party's leadership over the construction of the rule of law in public health through the judicial organs does not mean the intervention in the judicial justice of public health. On the contrary, it adheres to the leadership position of the party defined in the constitution, so as to provide sufficient support and guarantee for the people to feel fairness and justice in every case. The rule of law in public health is a way of social regulation and a choice of a democratic society (Foege, 2004). The construction of socialist public health rule of law is the choice of the people of the whole 
country and a consensus reached by the people of the whole country. Therefore, the process of its implementation is the process of the party's leadership of the state and society through the judicial organs of public health law implementation. The situation of China's vast territory and large population determines that the promotion mechanism of the construction of the legal implementation system of public health under the leadership of the party is essential to comprehensively promote the implementation of the goal of ruling the country according to law. However, in the process of implementing the rule of law in public health, it is inevitable to encounter problems, such as connection and coordination between public health management agencies and other institutions, and between public health management institutions across regions. In this context, based on the correct handling of the relationship between the party and the government, we should coordinate the relationship between different organs and regions. The promotion mechanism of the party's leadership in the construction of the public health legal implementation system focuses on the construction of the promotion mechanism for the implementation of the constitution. This is also the top priority of comprehensively promoting the rule of law. Only from the perspective of fundamental law, under the leadership of the party, promote the construction of the rule of law in public health, unswervingly promote the orderly advancement of all work in accordance with the Constitution and laws, and carry out on the track of the rule of law in public health, can we promote the effectiveness of the whole system of laws and regulations based on the constitution, and constantly improve the system construction and mechanism guarantee of the implementation system of the Constitution and law.

\subsection{The Implementation of the Party's Leadership over the Construction of the Rule of Law in Public Health through the Supervision Organs Focuses on the Improvement and Perfection of the National Supervision System}

After the 19th National Congress of the Communist Party of China, the reform of the national supervision system was carried out throughout the country, and the establishment of supervision institutions in various regions was promoted rapidly. The first session of the 13th National People's Congress passed the amendment to the constitution, which established the status of the state supervisory committee as the highest supervisory organ of the state, thus laying an organizational foundation for the implementation of the party's leadership over the construction of the rule of law in public health through the supervision organs. Article 2 of the State Supervision Law stipulates the basic position of adhering to the party's leadership in the development of state supervision, which also lays a normative foundation for the implementation of the party's leadership over the construction of the rule of law in public health through the supervision organs. Under the leadership of the party, the system reform of the supervision committee has been carried out, and the supervision organ has become an important support for promoting the legal development process of national su- 
pervision of public health under the leadership of the party. The construction of the rule of law in public health embodies the vital role of the party's leadership in the construction of a strict legal supervision system of public health, and plays an overall role in the integration of national supervision forces. The coordination mechanism of the party's leadership in the construction of public health legal supervision system integrates the supervision power from the height of national supervision system construction to form the Supervision joint force (Hodge Jr., 2003). The party's responsibility to supervise the political power should be combined with the good application of the principle of democratic centralism. Based on the people's democracy, the party's construction, system construction, corruption punishment and anti-corruption building should be unified into the legal construction of public health, and the system construction should be the focus to realize scientific, pragmatic and efficient decision-making. The Sixth Plenary Session of the 18th CPC Central Committee put forward that "Party committees at all levels should support and ensure that people's congresses, governments, supervisory organs and judicial organs at the same level supervise state organs and public servants according to law". On the track of the rule of law in public health, the organic combination of inner-party supervision and state supervision, the formation of an overall joint force at the level of legal supervision of public health, resolutely correcting the phenomenon of non-compliance with the law, and ensuring strict compliance with regulations are the basis for the construction of the coordination mechanism of the party's leadership in the construction of the legal supervision system of public health. Further analysis, from the perspective of collaborative mechanism construction, strengthening the party's leadership over the construction of the rule of law in public health is more powerful to make the supervision of the people's Congress, the party, public health judicial supervision, administrative supervision, audit supervision, social supervision in the high degree of national supervision, form a more rigorous public health legal supervision system, and carry out the overall implementation of the law Under the leadership of the Communist Party of China, we should implement the orderly promotion of public health legislation, public health law enforcement, public health justice and law-abiding, and ensure the sound operation of good governance.

\section{The Basic Principles of the Party Leading the Construction of the Rule of Law in Public Health}

\subsection{Adhering to the Party's Leadership over the Legal Construction of Public Health Is the Fundamental Principle of the Party's Leadership in the Construction of Public Health Law}

The party's leadership over the legal construction of public health is an important guarantee to realize the fundamental interests of the people. Under the leadership of the party, public health protection has become an important point of development for all kinds of undertakings of the party and the state. The ulti- 
mate goal of safeguarding the fundamental interests of the people is an important embodiment of the progressiveness of the party's advanced nature and the party's leadership system. In this sense, the party's leadership is the fundamental guarantee to promote public health legislation and public health security. Under the leadership of the party, the legal construction of public health is based on the fundamental interests of the people, and the reform of public health system is promoted. The relationship between the party and the law and the leadership system in line with the law of epidemic prevention and control has been formed. The construction of the ruling party representing the will of the people will guide the whole process of the construction and development of the rule of law in public health, give full play to the vital role of political organs in the construction of the rule of law in public health, and implement the concept of public health security in all aspects of national and social construction. The party's leadership over the construction of the rule of law in public health should be based on the public health protection and realize the organic unity of the will of the party, the will of the law and the will of the people.

\subsection{The Combination of Ruling the Country According to Law with the Party's Construction Is the Basic Principle of the Party's Leadership in the Construction of the Rule of Law in Public Health}

The party's leadership over the legal construction of public health is the fundamental guarantee to ensure the correct direction of the legal construction of public health. To strengthen the party's leadership over the construction of the rule of law in public health, we should not only promote the rule of law in the level of governing the country according to law, but also start from the process of promoting the rule of law according to law and the construction of the party, run the party building throughout the whole process of the construction of the rule of law in public health, promote the cohesion and coordination of inner-party laws and regulations and public health legislation, and on this basis, comprehensively promote the process of legal construction of public health. The leadership of the party is very important to effectively solve the legal problems of public health. Under the leadership of the party, the legal construction of public health can unify the actions of various organs and form the joint force of public health management. The party's leadership is carried out within the framework of the rule of law in public health, and promotes the important process of the party's leadership in the construction of the rule of law in public health at the level of combining the rule of law with the construction of the party (Blasbalg, 2000).

\subsection{It Is an Important Principle for the Party to Lead the Legal Construction of Public Health to Promote the Rule of Law, Governance and Administration in Accordance with the Law}

It is not only an important approach for the party's leadership, but also an im- 
portant principle for the party to lead the construction of the rule of law in public health. On the one hand, the core role of the party's leadership complements the legal performance of public health legislative organs and public health law enforcement organs, and jointly promotes the process of strengthening the party's leadership. On the other hand, the party, through the public health legislative organs and public health law enforcement organs, organizes and manages the society according to law, playing an irreplaceable important role, which constitutes the outstanding performance of the party's role of "taking over the overall situation and coordinating all parties". Adhering to the leadership of the party is the core of the legal system construction of social public health with Chinese characteristics. On this basis, the key to develop socialist democratic politics and improve the capacity of public health legal construction is to promote the process of governance, governance and administration in accordance with the law. The leadership of the Communist Party of China, proceeding from the fundamental interests of the people, has opened up an innovative path for the construction of the party's legal system. The construction of the innovative mechanism of the party's leadership in the construction of the inner-party laws and regulations is based on the perfection and perfection of the inner-party laws and regulations, the premise is the separation of the party and the government, and the effective connection between the inner-party laws and regulations and the national laws is the guarantee. We should adhere to the combination of the inner-party system and the national public health rule of law, proceed from the stricter requirements of the party's laws and regulations, firmly guarantee the development direction of public health and people's happiness, consolidate the party's ruling position, and provide fundamental political guarantee for the construction of public health rule of law. From the perspective of power supervision, it is very important to attach great importance to the authority of the party's constitution in the process of public health legal construction, which is very important for the implementation of the party's principles and policies in the construction of public health rule of law (Hunter, 2007). With the innovative mechanism of the party leading the construction of the inner-party legal system, we should comprehensively promote the construction of the rule of law in public health, ensure the people's attribute of the legal construction of public health, give full play to the wisdom and strength of the people, and form a joint force with the inner-party supervision mechanism, so as to implement the legal responsibility in the construction of the rule of law in public health, ensure that the right is used by the people and benefit the people. And to provide strong support for people's right to life and public health and health protection with a more mature and stereotyped public health legal system (Hodge, 2018). Under the guidance of Marxism, adhering to the party's leadership, promoting the continuous development and improvement of the inner-party legal system, ensuring that the people are the masters of the country, ensuring the orderly progress of the construction of the rule of law in public health, realizing the organic unity of 
the party's will and the people's fundamental interests, and condensing the powerful force of the great rejuvenation of the Chinese nation, constitutes the core value of the innovation mechanism of the party's leadership in the construction of the inner-party legal system pursuit.

\section{The Collaborative Path of the Party's Leadership in the Construction of the Rule of Law in Public Health}

The release of the effectiveness of the legal system of public health under the leadership of the party is based on the organic unity of the legal construction of public health and the party construction. The ability of the party to lead the rule of law in public health is an important part of the party's ruling ability and an important part of the construction of Marxist political parties. The leadership of the party, which represents the fundamental interests of the people, has become an important way to promote the legal construction of public health according to law. In this sense, only by adhering to the party's leadership of the construction of the rule of law in public health can we truly realize the development of the rule of law in public health with the fundamental interests of the people as the essence.

\subsection{The Coordinated Promotion of the Implementation of the Rule of Law in Public Health and the Legal Guarantee System under the Leadership of the Party}

Ruling the country according to law, consolidating the leading position of the party from the system, establishing the party for the public, and fundamentally establishing the party's purpose constitute the important foundation of the party's leading core role. The rule of law is inseparable from the leadership of the party. Under the guidance of building the party for the public and governing for the people, and taking the coordinated promotion of the process of governance, governance and administration in accordance with the law as the path, and under the guidance of the party's overall command and coordination of all parties, we fully support people's congresses, governments and judicial organs at all levels to strictly perform their functions in accordance with the regulations, divide work and cooperate, and jointly promote the construction of the rule of law in public health and implement the party's role in public health The leadership of health legal construction. In fact, the party's leadership plays an irreplaceable role in ensuring that state organs, social organizations and people's organizations coordinate with each other and actively carry out their work independently.

\subsection{Coordination and Cooperation between Public Health Management Institutions and Other Departments under the Leadership of the Party}

Under the leadership of the party, the public health management institutions should coordinate with other departments. Ruling by law is the basis for the legalization of Party leadership from the transformation of leadership style, and 
provides solid guarantee for the consolidation of the core position of the party in terms of advanced nature and people's nature. On the basis of the organic combination of ruling by law and Party building, we should enhance the authority and effectiveness of public health legislation, ensure the ability and level of public health law enforcement, and promote the construction of the rule of law in public health. The leading role of the party should start with construction and promote the development of the cause of the party and the state with practical actions, through the in-depth promotion of the party's construction process, to ensure the rule of law and promote the development and improvement of public health legal construction.

\subsection{Effective Coordination between the Party's Leading Public Health Legislation and Ensuring Public Health Law Enforcement}

In the process of legal construction of public health, from the perspective of public health management organization and mechanism construction, administration according to law can promote the play of the vital role of the party in overall planning and coordinating all parties, strengthen party building, improve the party's leadership from the construction of new party government relationship and performance guarantee, and correctly handle the relationship between the core role of the party's leadership and the full performance of public health management institutions according to law relationship. Specifically speaking, the role of the party's leadership in the construction of the rule of law in public health needs to make clear legal provisions and institutional arrangements for the functions and powers of public health management institutions, so as to realize the institutionalization of the relationship between the party and the government. At the same time, we should take democratic management as the path to promote the development of public health legal construction in the level of harmonious development of Party government relations, and coordinate the leading role of the party with the functions of public health management organs. The construction of public health legal guarantee system under the leadership of the party is an important embodiment of the party as the core of the cause leadership (Riley et al., 1977). On this basis, we should comprehensively improve the level of the construction of public health legal supervision system, effectively prevent the occurrence of phenomena that do not conform to the operation law of public health rule of law, establish the mechanism guarantee of resolving contradictions along the legal track in the operation level of public health legal supervision, so as to make the public health legal awareness deeply rooted in the hearts of the people, and form the rule of law idea of using legal thinking to deal with public health emergencies Through the construction of corresponding incentive and restraint mechanism, we can consolidate the achievements of the party's leadership in the construction of public health rule of law, and provide a strong guarantee for the development and improvement of the public health legal system. 


\section{Conclusion}

The main contribution and innovation of the study is to give full play to the institutional advantages of the party's leadership in public health rule of law, and analyze the basic laws, mechanisms, basic principles and collaborative paths of the party's leadership in the construction of public health rule of law. Under the leadership of the party, the legal construction of public health and the implementation of legal guarantee system, the coordination of public health management agencies and other departments, and the effective coordination of public health legislation and public health law enforcement under the leadership of the party provide normative support for the construction of a strong public health system. In the subsequent research, the suggestions on the collaborative path of public health law under the leadership of the party need to be tested and improved in practice.

\section{Fund Projects}

Funded by the state social science later stage "Research on China's public health legislation" (20FFXB043), Guangdong Province philosophy and Social Sciences planning special project "Research on the standard guarantee and path innovation of transforming the party's leadership fundamental system advantages into governance effectiveness" (GD20ZD06) and the Ministry of Education Special Commission project "empirical research and optimization path of the promotion effect of constitution and basic law in Macao Special Administrative Region" (JBF202003).

\section{Conflicts of Interest}

The author declares no conflicts of interest regarding the publication of this paper.

\section{References}

Blasbalg, G. B. (2000). Public Health Law. Roger Williams University Law Review, 5, 870.

Edgar, Jr., C. et al. (2003). Public Health. Roger Williams University Law Review, 8, 596.

Foege, W. H. (2004). Redefining Public Health. Journal of Law, Medicine and Ethics, 32, 23. https://doi.org/10.1111/j.1748-720X.2004.tb00178.x

Hodge Jr., J. G. (2003). Health Information Privacy and Public Health. Journal of Law, Medicine and Ethics, 31, 663. https://doi.org/10.1111/j.1748-720X.2003.tb00133.x

Hodge, J. G. (2018). Public Health Preemption: Constitutional Affronts to Public Health Innovaitons. Ohio State Law Journal, 79, 685-704 .

Hunter, N. D. (2007). Public-Private Health Law: Multiple Directions in Public Health. Journal of Health Care Law \& Policy, 10, 89.

Riley, J. W. et al. (1977). Public Health Care. Urban Lawyer, 9, 846. 